\title{
HABEO-PICTURE OF THE WORLD IN RUSSKAYA PRAVDA
}

\author{
Marina V. Milovanova \\ Volgograd State University, Volgograd, Russian Federation
}

\begin{abstract}
The article examines possessive relations reflected in the text of Russkaya Pravda. It gives a brief outline of the prototypical possessive relations including the subject-possessor, the object of possession and the second participant of the situation. The author characterizes the situations of possessive initiation, alienation and inheritance of the object, prevailing in Russkaya Pravda. The author marks a special necessity of using a number of verbs in the analyzed text to transfer relations of ownership. These verbs go back to the same root reflecting the world perception from Habeo viewpoint: izymati, emati, poimeti, poyati, priyati, imati, etc.

The author substantiates a close connection between the category of possessiveness and the concepts of locativity and existentiality. This connection has largely determined the availability of various linguistic means for expressing possessive relations in the language: structures with the verbs imet' (to have) and byt' (to be). The author demonstrates the expression of possessive relations by means of these using the etymological data. In particular, the conclusion is drawn on the connection of the verb imet'(to have) with an "initial point" of ownership, possession of something - (to take, to grab) unlike the verb byt' "to be" which primarily expresses the existence, state and establishment of this state, rather than possession and its initiation. It is alleged that the text of Russkaya Pravda in contrast to the modern Russian language, reflects world perception from the Habeo viewpoint - an active, dynamic ownership by animate, inanimate object in the framework of possessive relations.

Key words: category of possessiveness, possessive situation, Habeo-languages, Esse-languages, verb, locativity, existentiality.

УДК 81 '1

ББК 81.006 .3

Дата поступления статьи: 10.12.2016

Дата принятия статьи: 14.02.2017
\end{abstract}

\section{НАВЕО-КАРТИНА МИРА В «РУССКОЙ ПРАВДЕ»}

\author{
Марина Васильевна Милованова \\ Волгоградский государственный университет, г. Волгоград, Российская Федерация
}

\begin{abstract}
Аннотация. В статье рассматриваются посессивные отношения, отраженные в тексте «Русской Правды». Дается представление о прототипических посессивных отношениях, включающих субъекта-посессора, объект обладания и второго участника ситуации. Охарактеризованы посессивные ситуации приобщения, отчуждения и наследования объекта, преобладающие в «Русской Правде». В анализируемом тексте отмечена особая востребованность для передачи отношений собственности ряда глаголов, восходящих к одному корню, отражающему восприятие мира с позиций Наbео: изымати, емати, поимети, пояти, прияти, имати и др.

Обоснована тесная связь категории посессивности с понятиями локативности и экзистенциальности, которая во многом определила наличие различных языковых средств для экспликации посессивных отноше근 иметь-конструкций и быmb-конструкций. С привлечением этимологических данных показана специфи홍 ка выражения данными конструкциями отношений посессии, делается вывод о связи глагола иметь с «начальной точкой» владения, имения чего-то в своей сфере (брать, хватать), в отличие от глагола быть, который выражает прежде всего экзистенцию, состояние и становление этого состояния, но не посессию и ее начало. Утверждается, что в «Русской Правде», в отличие от современного русского языка, находит отражение восприятие мира с позиций Наbeо: активное, динамичное, деятельностное владение одушевленным, неодушевленным объектом в рамках отношений собственности.

Ключевые слова: категория посессивности, посессивная ситуация, Наbeо-языки, Еsse-языки, глагол, локативность, экзистенциальность.
\end{abstract}


«Русская Правда» относится к числу памятников, которые исследованы специалистами различных областей научного знания, поскольку, несмотря на небольшой объем, содержит ценный материал исторического, правового, культурологического, филологического характера.

Центральное место в данном памятнике занимают отношения собственности. Понятие владения, собственности является одним из основополагающих в процессе познания человеком окружающей действительности и находит отражение во всех естественных языках. Данное понятие находится, безусловно, в сильной зависимости от культуры, особенностей менталитета носителей языка.

Институт собственности имеет длительную историю развития. На протяжении всей своей жизни человек всегда чем-то и кем-то владел. Вместе с развитием института собственности развивались и средства отражения этого понятия в языке.

В тексте «Русской Правды» в рамках института собственности представлено именно то, что было актуальным и востребованным для носителей языка периода XI-XII веков. Нам представляется интересным обратиться к «Русской Правде» как к тексту, в котором нашла яркое отражение так называемая Наbео-картина мира.

Понятие собственности составляет основное содержание универсальной категории посессивности. Именно представленность в языках категории посессивности позволяет провести деление на Habeo- и Esse-языки. B Habeo-языках (например, немецком, английском) центральной посессивной конструкцией является конструкция с глаголом иметь, которой в Esse-языках (например, русском) соответствует конструкция с глаголом быmb. Следует заметить, что глагол иметь в Esseязыках также может быть употреблен в посессивной конструкции, ср.: У меня есть недвижимость - Я имею недвижимость, однако такие предложения обычно характеризуют как стилистически маркированные (книжные).

Habeo и Esse - это особый, отличающийся взгляд на мир и свое место в нем. Русский язык ученые традиционно относят к Esse-языкам. Однако, как отмечает Н.Д. Арутюнова, «в древнерусском языке глагол им $\mathbf{k} и$ был широко распространен в разных значениях и такая его широкая представленность позволяет говорить о древнерусском языке как о языке смешанного типа» [Арутюнова, 1999, c. 791].

Как же развивались в русской лингвокультуре представления о посессии? Прежде чем обратиться к материалам «Русской Правды» (Краткой и Пространной редакций), рассмотрим ключевые аспекты универсального понятия «посессивность».

\section{2}

Посессивность в самом общем виде представляет собой выражение отношений между двумя сущностями - посессором и объектом посессивности, первый видится имеющим некоторые отношения со вторым, находящимся в непосредственной близости или под контролем первого. В силу своей значимости и объемности для концептосферы человека данное понятие трактуется как категория.

Категория посессивности предполагает посессивные ситуации, которые весьма разнообразны и могут включать различные действия субъекта; указание на возможное месторасположение объекта; второе лицо, от которого субъект отчуждает объект либо кому объект передается, и другие параметры. Иными словами, посессивную ситуацию можно представить следующим образом: существует некий объект, который субъект взял или получил, который расположен в сфере существования субъекта, который может регулярно сопровождать субъекта в определенных случаях и может интерпретироваться как принадлежащий субъекту.

Посессивная ситуация отражает посессивные отношения, которые и составляют основу категории посессивности. Прототипические посессивные отношения включают посессора - лицо и обладаемое - конкретный предмет, часть тела или члена семьи данного лица [Гиро-Вебер, Микаэлян, 2004, с. 65]. Профессор кафедры славянского языкознания Цюрихского университета Даниэль Вайс предлагает 
разграничивать также «сильную», или «подлинную», посессивность (посессор = владелец предмета) и «слабую» (посессор имеет контроль над предметом) [Вайс, 2004, с. 285].

Достаточно подробно и широко посессивные отношения описаны в работах О.Н. Ceливерстовой: сфера посессивности X-a - это все то, на что распространяется «личность» $\mathrm{X}$-a, это то, что попадает под временную или постоянную власть Х-а (юридическую, физическую, нравственную, духовную), с другой стороны, то, что несет в себе элемент самого $\mathrm{X}-\mathrm{a}$, причем этот элемент является производным, зависимым от X-а [Селиверстова, 2004].

Представленная характеристика универсального понятия посессивности, на наш взгляд, должна быть дополнена еще одним важным структурным компонентом - вторым субъектом, который также имел, имеет, будет иметь (либо намеревается) какое-либо отношение к объекту посессии (причем его действия могут носить как законный, так и противоправный характер). Второй субъект может противодействовать субъекту-посессору владеть объектом либо оказывать ему содействие и т. П. Словом, второй субъект посессивных отношений - это тот, кто тем или иным образом (намерения, действия) включает в свою сферу (ментальную, физическую) объект посессии. Формально данные отношения можно представить в следующем виде: $\mathrm{S} 1 \leftarrow \mathrm{Ob} \rightarrow \mathrm{S} 2(\mathrm{n})$. Однако если мы будем говорить об отношениях посессии не вообще, а применительно к таким сферам, как экономика и право, то будет представлена так называемая третья сторона - в лице того, кто дает оценку данному виду отношений, например, в Древней Руси в качестве такой третьей стороны мог выступать княжеский суд.

3

В тексте «Русской Правды» Краткой и Пространной редакций представлен в самом общем виде следующий тип посессивных отношений: в качестве субъекта-посессора выступает лицо, которое обладает определенной (как правило, полной) властью над объектом; объект - конкретный предмет, лицо либо объект расширенного характера; отношения между субъектом и объектом характеризу- ются как «сильные», поскольку посессор является владельцем объекта. Таким образом, отраженная в тексте сфера посессивности включает в себя все, на что распространяется личность посессора, что (кто) находится под его постоянной властью или зависит от него. В качестве второго субъекта, согласно данным памятника, могли выступать прежде всего лица, незаконно отчуждающие объект посессии, либо наносящие ему вред, либо препятствующие возврату (в современном юридическом дискурсе - преступники); лица, оказывающие содействие в возвращении объекта субъекту-собственнику; лица, претендующие на объект (ситуация наследования). Третьей стороной выступал, безусловно, княжеский суд, который давал свою оценку ситуации: устанавливал определенный вид наказания.

Из текста памятника следует, что во времена его составления посессивные отношения преполагали полное господство субъекта-собственника. В состав субъекта-посессора включались все свободные люди. В качестве объектов посессии выступало движимое и недвижимое имущество. К недвижимому имуществу относилась прежде всего земля (и постройки хлев и др.), а также двор, дом: $A$ двор без дела отень всяк меншему сынови (РП ПР, ст. 100) ${ }^{1}$; Аже кто умирая разд свои дттемь, на том же стояти; паки ли безъ ряду умреть, то вс $\mathbf{k} и ъ$ дет $\mathbf{k} и$, а на самого часть дати души (РП ПР, ст. 92).

Движимое имущество можно объединить в следующие группы: домашние животные (овца, коза, конь и др.), птица (гусь, утка, лебедь и др.); ловчие птицы (ястреб, сокол); ценные предметы (оружие, одежда); бытовые жизненно важные предметы (сено, дрова). Отдельную группу движимого (и недвижимого) имущества составляли объекты расширенного характера: добыток, дом, двор, задница (наследство).

О значимости собственности для древнего русича свидетельствует целый ряд единиц, номинирующих имущество. Так, самое общее обозначение собственности заключено в единице имение: в словаре И.И. Срезневского им tнuе - имущество (которое можно было продать, возвратить, завещать и т. д.), а также богатство, мзда, добыча, зах- 
ват (Срезневский, т. I, стб. 1094-1095); имущество, добыча, богатство, мзда, земельное владение, захват (СРЯ XI-XVII, вып. 6, с. 226227). Обратим внимание на то, что важной составляющей понятия имущества является способ его приобретения - захват, добыча (в современном русском языке это значение у единицы имущество не эксплицировано). Однако в «Русской Правде» данная единица не зафиксирована, имущество обозначено другими языковыми единицами - добытокъ, задница (наследуемое имущество), домъ.

Языковая единица домъ в древнерусском языке имела более широкое значение по сравнению с современным русским языком. B.М. Живов трактует домъ как «древнейший русский термин для обозначения имущества (движимого и недвижимого)» [Живов, 2002, c. 196], известный русский ученый-цивилист П.П. Цитович считает, что понятие дом тесно связано с другим функционально обусловленным обозначением имущества - задница: дом и заднииа выражают только различные стороны одного и того же понятия - имущества умершего, имущества как целого, universitas. Это имущество, эта целостность со стороны своей принадлежности покойному при его жизни называется домом. Но то же самое имущество со стороны возможности достаться другим через посредство наследования представляется как нечто оставленное, покинутое позади себя умершим и поэтому называется задницей, остатком, статком [Цитович, 1870, с. 56-57]. Приведем контексты из «Русской Правды»: Аже кто умирая разделить дом свои детем, на том же стояти (РП ПР, ст. 92); Аже в боярех любо в дружине, то за князя задниця не идеть (РП ПР, ст. 91); Аже жена сядеть по мужи... а задниця ей мужняя не надобе (РП ПР, ст. 93); Аже будеть сестра в дому, то той заднице не имати (РП ПР, ст. 95). В ситуации наследования (в обозначенный хронологический период) четко прослеживаются гендерные различия в праве на наследование.

Особого внимания заслуживает единица добытокъ: Аже жена ворчеться седети по мужи, а ростеряеть добыток и поидеть за мужь, то платити ей все детем (РП ПР, ст. 101); Аже будуть в дому д кти мали, а не джи ся будуть сами собою печаловати, а мати имь поидеть за мужь, то кто имь ближии будеть, тому же дати на руи $\mathbf{k}$ и добыткомь и с домомь, донел ж же возмогуть; а товарь дати перед людми; а что

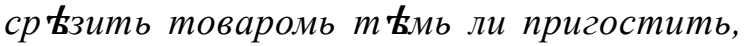
то то ему соб $\mathbf{k}$, а истьи товарь воротить имъ, а прикупь ему соб $\mathbf{k}$, зане кормиль и печаловалься ими... (РП ПР, ст. 99). Данная единица также называла имущество, при этом в ее значении прослеживается связь с начальным моментом имения чего-то, эксплицирован динамический аспект собственности: прежде чем что-то иметь, надо для этого применить усилия - завоевать, получить с помощью собственного труда и т. д. В Словаре И.И. Срезневского добытъкъ - имущество, имение; добыча (Срезневский, т. I, стб. 685). В Словаре русского языка XI-XVII вв. первым значением приводится «добыча», а вторым - «имущество, состояние» и затем - «доход, прибыль» (СРЯ XI-XVII, вып. 4, с. 272). В современном русском языке слово добыток утратилось, остались родственные добывать, добытчик, добыча.

Итак, между субъектом-посессором и зависимым от него объектом устанавливаются определенные посессивные отношения, ядерными средствами выражения которых в языке выступают глагольные единицы, квалифицирующие определенные посессивные ситуации. При этом следует отметить особую востребованность в «Русской Правде» для передачи отношений собственности ряда глаголов, восходящих к одному корню, отражающему восприятие мира с позиций Habeo: uзымати, емати, поимети, пояти, прияти, имати и др.

В тексте «Русской Правды» представлены различные посессивные ситуации. Преобладают ситуации приобщения объекта (взять штраф, забрать кого-, что-либо, присвоенное незаконным путем, назад и т. д.): Или будеть кровавъ или синь надъраженъ, то не искати ему видока челов тку тому; аще не будеть на немь знамениа никоторагоже, то ли приидеть видокъ; аще ли не можеть, ту тому конець; оже ли себе не можеть мьстити, то взяти ему за обиду 3 гривн $\mathbf{k}$, а л ттияю мъзда (РП КР, ст. 2); Аже кто даеть куны в р $\mathbf{k} з$, или наставъ в медъ, или жито во просопь, то послухи ему ста- 
вити: како ся будеть рядиль, тако же ему имати (РП ПР, ст. 50); Аже у господина ролеиныи закупь, а погубить воискии конь, то не платити ему; но еже даль ему господинь плугь и борону, от него же купу емлеть, то то погубивще платити... (РП ПР, ст. 57); Или холопь ударить свободна мужа, а б ъжить въ хоромь, а господинь начнеть не дати его, то холопа пояти, да платить господинь за нь 12 гривн ' (РП КР, ст. 17).

Примечательно, что достаточно часто в ситуации приобщения употребляется местоимение свои, которое подчеркивает полную власть над одушевленным объектом, закрепляет отношения собственности - контексты типа: $A$ челядинъ скрыеться, а закличють $u$ на торгу, а за 3 дни не выведуть его, а познають и третии день, то свои челядинь поняти, а оному платити 3 гривны продажи (РП ПР, ст. 32); Аще поиметь кто чюжь конь, любо оружие, любо порть, а познаеть въ своемь миру, то взяти ему свое, а 3 гривн ъ за обиду (РП КР, ст. 13).

Отдельно следует остановиться на зафиксированном в тексте глаголе переимати, который обозначает ситуацию временного интенсивного приобщения одушевленного объекта, при этом субъект не является собственником, он лишь на определенное время включает объект в свою сферу, чтобы впоследствии вернуть его истинному владельцу; префикс пере- передает момент отчуждения объекта у одного лица и приобщение его другим лицом, а также опосредованно указывает на временный характер посессивных отношений: Аже кто переиметь чюжь холопь $u$ дасть в $\mathbf{k}$ сть господину его, то имати ему переемь гривна; не ублюдеть ли, то платити ему 4 гривны, а пятая переемная ему, а будеть роба, то 5 гривенъ, а шестая на переемъ отходить (РП ПР, ст. 113).

Весьма интересным в аспекте экспликации отношений собственности является выражение, неоднократно отмеченное в тексте, лицемь взяти (пояти). Лицемъ, по материалам Словаря И.И. Срезневского, - «поличное» (Срезневский, т. II, стб. 31), то есть взять, забрать именно то, что лично принадлежало субъекту, именно этот предмет, это лицо, а не что-то другое; помимо этого, лицемь означа- ет также, что объект должен быть представлен в наличии (то есть «в присутствии»), причем в контексте может быть тройное указание на собственность субъекта - взять, лииемь, свое: Аче кто конь погубить, или оружье, или порть, а запов Ссть на торгу, а посль познаеть въ своемь город $\mathbf{k}$, свое ему лицемь взяти, а за обиду платити ему 3 гривны (РП ПР, ст. 34); ...яже от челяди плод или от скота, то то все поимати лицемь; что ли будеть ростеряль, то то все ему платити д $\mathbf{k} т е м ь ~ m \mathbf{k} и ;$ аче же и отчимь прииметь д $\mathbf{k} т и$ съ задницею, то тако же есть рядъ (РП ПР, ст. 39). В данных контекстах местоимение свои также подчеркивает отношения собственности, власти субъекта. При этом зафиксирована следующая закономерность: в ситуациях с неодушевленным объектом в большинстве случаев приобщение выражают глаголы взяти, имати, в ситуациях с одушевленным объектом - глагол пояти, который передает более интенсивное действие, подчеркивает сильное желание субъекта возвратить объект в свою личную сферу, указывает на определенные усилия.

Следующей посессивной ситуацией является ситуация отчуждения - по сути, та же ситуация приобщения, однако акцент делается именно на отчуждении объекта у другого лица, участвующего в ситуации, причем в качестве объекта выступает собственность субъекта, поэтому он ее отчуждает на законных основаниях; в большинстве случаев это одушевленный объект, на который полностью распространяется власть субъекта-посессора: Или холопь ударить свободна мужа, а бъжить въ хоромъ, а господинъ начнеть не дати его, то холопа пояти, да платить господинъ за нь 12 гривн ' (РП КР, ст. 17); Аже украдуть овъиу, или козу, или свинью, а ихъ будеть 10 одину овьиу украл $\mathbf{k}$, да положать по 60 р ъзанъ продажи; а хто изималь, тому 10 р ъзанъ (РП КР, ст. 40).

Отдельно следует рассмотреть посессивную ситуацию наследования, которая широко отражена в Пространной редакции «Русской Правды». Для обозначения данной ситуации чаще других использованы глаголы имати, поимати: Аже будеть сестра в дому, то тои задниц не имати, но отдадять ю за мужь братия, како си могуть (РП ПР, 
ст. 95); ... а товарь дати перед людми; а что ср $\mathbf{k}$ зить товаромь т $\mathbf{k}$ мь ли пригостить, то то ему соб $\mathbf{k}$, а истыли товарь воротить имъ, а прикупь ему соб $\mathbf{k}$, зане кормиль $и$ печаловалься ими; яже от челяди плод или от скота, то все поимати лицемь (РП ПР, ст. 99). Обратим внимание на последний пример. Наследство включает добыток - то есть движимое имущество и дом - недвижимое имущество (хотя, как мы уже отмечали, лексема дом могла обозначать в том числе и движимое имущество). Выражение поимати лицем в данном случае указывает на то, что наследство должно быть передано все, полностью, субъект должен все забрать в наличии, видеть это, тем самым обозначая границы своей власти.

\section{4}

Выделим ряд этимологически родственных глагольных единиц, представленный в «Русской Правде» в рамках посессивных ситуаций: яти, имати (формы настоящего времени с корнем емл-), им $\mathbf{k m u , ~ п р о и з в о д н ы е ~}$ възяти (възимати), пояти (поимати), прияти (приимати), переимати. В большинстве случаев эти глаголы отражали в древнерусском языке ситуацию приобщения объекта, начальный момент посессии. Приведенные единицы обнаруживают структурно-грамматическую общность (генезис корневой морфемы, характер парадигм, соотношение основ и суффиксов-флексий). Данные глаголы прошли длительный путь структурно-семантической эволюции, которая обусловлена целым рядом сложных исторических процессов. Можно предположить, что в праиндоевропейском корень глаголов яти, имати, им $\mathbf{k}$ состоял из одного согласного - это был краткий диезный слоговой сонорный - $m$-. Впоследствии в результате действия определенных тенденций в праславянском языке этот корень преобразовался в чередующиеся дифтонгические сочетания *-ӗm- $/$ *-ım-, которые, в свою очередь, изменились в *-еm-/*-ьт-. Данные дифтонгические сочетания и приняли участие в образовании глаголов яти, имати, им $\mathbf{k} т и$ [Милованова, 2007, с. 133].

В некоторых славянских языках до сих пор сохранились формы, свидетельствующие о наличии в корне дифтонгического сочетания с носовым согласным, например, в польском: wziqć - взять (Фасмер, т. I, с. 311).

В приведенном ряду глаголов особое место занимает глагол им $\mathbf{k} m u$. М. Фасмер считал, что имамь, им тmи связаны с праславянским *jьmo : *jęti и отношение $a: e$ является древним (Фасмер, т. II, с. 128). Вяч.Вс. Иванов также, говоря об отношении $a: e$, указывает, что глагол *јьтать является «единичным остатком древнего типа основ на $\bar{a}$, где $\bar{a}-$ суффикс, обозначающий состояние и связанный с ё» [Иванов, 1981, с. 132]. Весьма интересны взгляды А. Преображенского: ученый, говоря в целом о глаголе им $\mathbf{k} m u$, связывал его не с $я т и$, а с имати, однако не со всеми формами глагола имати, а только с формами типа емлю и считал, что $u м \mathbf{k m u}$ - это несовершенный вид к многократному емлю; значения автор соотносил следующим образом: «что я взялъ (емлю), то у меня есть, то я им tю» (Преображенский, с. 270).

В современном русском языке в результате длительного и сложного процесса исторического развития данный глагольный ряд представлен несколько иначе. Так, парадигма глагола яти полностью утратилась, от него сохранились лишь префиксальные образования совершенного вида: взять, возьму; принять, приму и т. д. В качестве видовой пары у глагола взять в современном русском языке закрепился не глагол имати, а глагол несовершенного вида брать, имеющий с ним общее лексическое значение. От глагола $u м a-$ ти сохранились лишь префиксальные образования несовершенного вида в качестве видовой пары соответствующим образованиям от яти: принимать - принять, отнимать отнять и т. д.

В современном русском языке сохранились также образования с корнем -емл'- (производимые от имати), которые часто приобретают книжную стилистическую окраску, употребляясь в книжных (художественных) текстах: Восстань, пророк, и виждь, и внемли... (А.С. Пушкин).

Что касается глагола пояти, то его парадигма утратилась, сохранилась форма поймать (от глагола поимати), в узком значении в качестве видовой пары к ней закрепился глагол ловить. 
Из бесприставочных образований в современном русском языке полностью сохранилась парадигма тематического варианта спряжения глагола $и м \mathbf{k} т и$.

Почему же в современном русском языке, в отличие от «Русской Правды», данный глагольный ряд не представлен в рамках посессивных отношений? Безусловно, на материале одного памятника письменности сложно делать обобщающие выводы. Однако ценнейший языковой материал, представленный в тексте «Русской Правды», позволяет поразмышлять над тем, что в рамках выражения собственности было действительно важным для носителя языка того времени и почему релевантной была именно Habeo-картина мира.

\section{5}

Обратимся к универсальной категории посессивности, ядро которой составляют отношения собственности. Как известно, язык является результатом процессов, которые происходили много лет назад, и диахронический подход - это мощный инструмент в объяснении языковой структуры. На вопрос, почему существует некоторая грамматическая категория и почему она имеет именно ту структуру, которую имеет, нельзя ответить полностью, если исследовать категорию только с синхронической точки зрения и не принимать в расчет факторы, благодаря которым появилась данная категория. Тем не менее даже такое «комплексное» объяснение категории может быть недостаточным, если не объяснять, в какой степени она является результатом исторического развития. На основании этих положений необходимо особо остановиться на связи понятия посесивности с локативностью и экзистенциальностью.

На связь данных понятий обращали внимание многие отечественные и зарубежные ученые (см.: [Апресян, 1995; Гиро-Вебер, Микаэлян, 2004]). В качестве аргументов в пользу их взаимосвязи ученые приводят тот факт, что во многих языках наблюдается структурное сходство между локативными, посессивными и экзистенциальными конструкциями (см.: [Lyons, 1967; Clark, 1978]). Эта связь проявляется по-разному в конкретном языке. В частности, экзистенциальные конструкции часто соответствуют одному типу посессивов, локативы - другому (порядок слов, определенность / неопределенность объекта посессивности и выбор глагола и др.).

Второй аргумент в пользу взаимосвязи данных понятий основывается на замечании Э. Бенвениста о том, что иметь (have) является обратным быть (be). Если иметь является обратным быть, то тогда пассив глагола иметь будет соответствовать быть, то есть приобретет экзистенциальное значение [Benveniste, 1966]. Как отмечают И. Бэрон и М. Херзлунд, пассивные конструкции с иметь встречаются редко, возможно, потому, что иметь, как и быть, является глаголом состояния, а данные глаголы нелегко перевести в пассивный залог. Тем не менее в датском у глагола have (иметь) есть форма пассивного залога haves, которая имеет ограниченную сферу употребления в значении «быть», «существовать», то есть используется в основном в экзистенциальных конструкциях [Baron, Herslund, 2001, p. 12].

В качестве еще одного аргумента тесной связи локативности и посессивности можно привести наличие в конструкциях с глаголом иметь указания на точное местоположение объекта: Он имеет дом в Испании (У него есть дом в Испании); объект (дом) находится в определенных посессивных отношениях к субъекту-посессору и в определенных локативных отношениях относительно конкретного месторасположения.

Связь между посессивностью, экзистенциальностью и локативностью во многом объясняет проблему так называемых источников посессивных конструкций в языках. Б. Хайне установил, что конструкции с глаголом иметь почти без исключений производны от следующих конструкций-схем: действие (X берет Y); локативность (Y располагается в (на) X); цель (Y существует для $\mathrm{X})$; генетивность (принадлежность) (существует Y, принадлежащий X); сопровождение (X (вместе) с Y); топикализация (Y существует относительно $\mathrm{X}$ ); источник (Y существует от (из) Х) [Heine, 1997].

Таким образом, категория посессивности тесно связана прежде всего с категорией локативности, а также с категорией экзистен- 
циальности. Любое обладание субъекта объектом - в различных его фазах: начало, собственно обладание, завершение - осуществляется в определенном пространственновременном континууме. Именно тесная связь посессивности с экзистенциальностью и локативностью во многом определила наличие различных языковых средств для выражения посессивных отношений в языках: иметь-конструкций и быть-конструкций.

\section{6}

Предикативные конструкции с глаголами иметь и быть относят к универсальным способам выражения посессивности (см.: [Benveniste, 1966 и др.]). Русский глагол бытьь и бытийный тип предложений, включающий посессивную модель, достаточно полно описан в лингвистической литературе - структуpa, семантика этих предложений, прагматика, коммуникативные признаки и т. д. [Арутюнова, Ширяев, 1983; Селиверстова, 2004; Babby, 1980; Paillard, 1984 и др.].

Глагол быть, являющийся основной посессивной конструкцией в русском языке, исследован с различных сторон, что обусловлено многообразием значений, которые он может выражать, - от собственно лексических до грамматических. Если обратиться к материалам толковых словарей, то в семантике глагола быmb можно выделить в качестве основных (но далеко не всех) следующие виды значений: локативные, экзистенциальные, посессивные и связочные. Однако следует учитывать тот факт, что собственно посессивное значение глагол быть приобретает только в сочетании с «y + генетив». Ряд исследователей считают, что посессивная конструкция с глаголом быть в русском языке восходит к модели локативной, в ходе грамматикализации синтагма «y + генетив» превратилась в «посессивный падеж», который обозначает посессора не только в собственно посессивной предикативной конструкции, но и в приглагольной позиции - там, где обладание или не обладание объектом не входит в ассерцию (см. об этом: [Гиро-Вебер, Микаэлян, 2004]). Другие ученые высказывают мнение, что посессивное предложение с глаголом быть появляется в результате семантического разви- тия бытийной конструкции с локальным компонентом [Мишланов, 2002]. Р.М. Бирюкович считает, что в основе конструкций «У Х есть $\mathrm{Y}$ ( (ситуация существования) и «X имеет $\mathrm{Y}$ » (ситуация обладания) лежат разные ономасиологические структуры, поскольку в ролевой структуре бытийных предложений один актант - субъект. Компонент бытийных предложений, представляющий собой область бытия, не становится участником ситуации (актантом), а являет собой лишь семантический дополнитель признакового понятия. В ролевой структуре предложений, обозначающих ситуацию обладания, - два актанта: субъект обладания и объект обладания [Бирюкович, 1990, с. 4].

Глагол иметь в русском языке традиционно исследовался прежде всего с позиций грамматики, как, например, вспомогательный глагол [Кацнельсон, 1949; Мещанинов, 1948, c. 175]. Однако, как отмечают М. Гиро-Вебер и И. Микаэлян, его роль в языке «не столь маргинальна, как принято считать» [Гиро-Вебер, Микаэлян, 2004, с. 54]. Существуют различные точки зрения на возникновение глагола иметь в русском языке. Например, известный славист А.В. Исаченко считал, что в общеславянском не было глагола иметь, он появился лишь в старославянском при переводе с греческого в составе калек [Isačenko, 1974]. Дж. Дингли обосновывает точку зрения, что глагол иметь унаследован восточнославянским языком из позднего общеславянского [Dingley, 1995].

Глагол иметь был широко распространен в древнерусском языке и входил в один ряд с родственными глаголами, обозначающими вступление в посессию, -яти, имати. В истории русского языка четко прослеживается последовательность становления посессивных отношений - сначала яти или имати и затем - им қmи. В современном русском языке развитие получили конструкции с глаголом иметь, в которых объект является абстрактным, что объясняется прежде всего типом дискурса, в котором такие конструкции употребительны. Это прежде всего язык, ориентированный на книжную, письменную речь. Мы разделяем точку зрения М. Гиро-Вебер и И. Микаэлян [Гиро-Вебер, Микаэлян, 2004] и считаем глагол иметь собственно посессив- 
ной глагольной лексемой, поскольку, в отличие от конструкций с глаголом быть, субъектпосессор при данном глаголе является также и грамматическим субъектом и выступает как активное начало в высказывании (ср.: Я имею недвижимость и У меня есть недвижимость). Конструкции с глаголом иметь востребованы в современном русском языке прежде всего в юридическом дискурсе именно в силу большей определенности.

Фактический материал «Русской Правды», как мы уже отмечали, отражает Habeoкартину мира, о чем свидетельствует система языковых средств - глагольных единиц, выражающих отношения собственности.

Почему же в русском языке произошло развитие именно быть-конструкций? Здесь следует обратиться к специфике формирования и развития концептосферы посессивности, о чем мы уже частично говорили. Посессивность следует рассматривать как отношение с перманентными свойствами, развитие посессивных отношений в языке не представляет собой линейный процесс, направленный в одну сторону. Можно говорить о том, что это про-активное (настоящее и направленное в будущее) и ре-активное (обращенное к прошлому) освоение личностью объектов внешнего мира. В самом общем виде посессивность является отношением между личностью и объектами внешнего мира. В этих отношениях есть некая начальная точка и последующая динамика - дальнейшее освоение личностью мира, развивающаяся от неотчуждаемой посессивности к отчуждаемой. Человек, освоив личную сферу, идет дальше, приобщая объекты уже за пределами его личной сферы. Самыми простыми и тем не менее наиболее естественными являются отношения, неотъемлемые от понятий, относящихся к самому себе (self): названия частей тела, родственные отношения, сфера личных отношений («sphere personnelle») (см.: [Balli, 1926]), то есть случаи, когда посессор неотделим от объекта посессивности. Посессор выражен наиболее четко именно в виде личности или подобного ей объекта. Про-активное освоение личностью объектов внешнего мира показывает, каким образом объекты вне «sphere personnelle» усваиваются личностью (self). Здесь мы переходим к таким понятиям, как «приобретение», «владение», «принадлежность», которые и составляют сущность посессивности.

Вместе с тем максимально контролируемый или отчужденный объект посессивности всегда имеет обратную связь с посессором, то есть с личностью. Таким образом, реактивность возвращает личность назад, к начальной точке.

Например, в немецком языке в конструкции Ich habe (я имею) и в английском языке в конструкции I have отразилось посессивное освоение личностью объектов внешнего мира, которое можно охарактеризовать как про-активное движение. В свою очередь, об инверсивном, ре-активном движении свидетельствуют следующие этимологические связи: готское hafjan - «завладеть, схватить» и его латинское соответствие (родственное слово) capio - «завладеть, схватить». Другими способами достижения того же эффекта являются претерито-презентные формы глагола в готском aigan / aih - «владеть, быть хозяином чего-либо» или формы среднего залога (медиального) в санскритском isse - «быть хозяином, контролировать», где посессивность выражается не дополнением, а подлежащим (см.: [Seiler, 2001]).

Обратимся к этимологии глагола иметь в русском языке. В историко-эимологическом словаре П.Я. Черных: иметь - «обладать, владеть, располагать чем-либо», украинское мати, болгарское имамь, сербское имати и др., корень jъm- (< bm- - «возьму», «схвачу»; значение «владеть», «обладать» развилось из значения «брать», «захватывать» (Черных, т. I, с. 344). М. Фасмер связывает по происхождению все названные глаголы. Так, име́ю, др.-русск., ст.-слав. им қmи, имамь. От *jьmo : jęti; см. взя́mь. Кроме того, см. имамь (Фасмер, т. II, с. 129). Глагол имамь, в свою очередь, также связан с праслав. *jьmо : *jęti (Фасмер, т. II, с. 128); емлю - има́ть «брать», несверш. из. *jьmǫ, *jęti (см. возьмý, взять), словен. jémljem, jemáti, чеш. jímati «хватать», слвц. jímat', полаб. је̃те «берет, хватает, ловит». Ср. лат. ето̄, ёmi «беру» (Фасмер, т. II, с. 19). Взять, возьму - из приставки vъz и је̧ti (Фасмер, т. I, с. 311). Таким образом, этимология русского иметь перекликается с этимологией глаголов have, haben в английском, 
немецком языках. Однако, как свидетельствуют приведенные данные, в Наbeo-языках в большей степени подчеркивается статус субъекта-собственника - завладеть, быть хозяином, в отличие от русского языка, но русский глагол иметь также связан с «начальной точкой» владения, имения чего-то в своей сфере - брать, хватать, то есть в данном случае в семантике глагола нашел отражение как момент про-активности, так и ре-активности в рамках посессивных отношений. Однако русский язык пошел по пути Esse-языков, быть-конструкции стали вытеснять uмeть-конструкции при выражении посессии.

В этимологии глагола быть не прослеживается связи с начальным моментом приобщения объекта. Так, быть в словаре П.Я. Черных: «существовать», «находится», «проявляться», укр. бути, бувати, белорус. быиь, бываци, словен. biti и др. родственно др.-инд. bhu«быть», «возникать», «являться», «жить», bhūtám - «существо», «мир»; автор приводит мнение Юлиуса Покорного, который связывал данный глагол с индоевропейским корнем, имеющим значение «быть», «возникать», «расти» (Черных, т. I, с. 129). В словаре М. Фасмера былть - родственно лит. búti «быть», др.-инд. bhưtís, bhūtiș «бытие, хорошее состояние, преуспевание», ирл. buith «бытие», далее, др.-инд. bhávati «есть, имеется, происходит», греч. $\varphi v ́ o \mu \alpha \imath$ «становлюсь», лат. fui «я был», futūrus «будущий», гот. bauan «жить» (Фасмер, т. I, c. 260) - то есть данная единица выражает прежде всего экзистенцию, состояние (обратим внимание - хорошее) и становление этого состояния, но не посессию и ее начало.

Итак, мы можем говорить о том, что в семантике предикативных конструкций, выражающих посессивные отношения, в русском языке (Esse-язык) находит отражение про-активный процесс освоения объектов внешнего мира, не включающий в себя момент ре-активности, поэтому связанный с настоящим и обращенный к прошлому, в отличие от Habeoязыков, в которых это про-активный процесс освоения объектов внешнего мира, включающий в себя момент ре-активности, поэтому направленный в будущее.
Однако фактический материал «Русской Правды» свидетельствует об обратном - частотность глагольных единиц, этимологически восходящих к значению «брать, хватать», позволяет говорить о релевантности данного аспекта для древних русичей. Причем начальный момент собственности был более значим, чем само владение, ведь «имение» и «захватывание» закрепляются за разными этимологически родственными глаголами - яти, има$m u$ (взять, схватить, брать) и им 'тmи (иметь). $\mathrm{B}$ «Русской Правде» нашло яркое отражение восприятие мира с позиций Нabeo - активное, динамичное, деятельностное владение одушевленным, неодушевленным объектом в рамках отношений собственности.

Мы можем предположить, что в рамках категории посессивности вытеснение быmbконструкциями $u$ мет $b$-конструкций во многом было обусловлено этнокультурной спецификой, отличающимся от других этносов восприятием отношений собственности. Русская культура, как известно, коллективистская культура; одной из констант русского национального самосознания является соборность. Посессивность и экзистенциальность, как мы уже отмечали, тесно связаны друг с другом, в каждой лингвокультуре эта взаимосвязь проявляется по-разному, в русской лингвокультуре посессия выражается через экзистенцию. Носитель русского языка воспринимает собственность через объект - у меня есть нечто, то есть это нечто существует в моей сфере, при этом без расширения непонятно, а принадлежит ли это нечто мне. В хронологический период, отраженный в тексте «Русской Правды», для носителя языка было актуально иное восприятие собственности, как и в целом посессивных отношений. Ведущим принципом познания окружающего мира и осмысления своего места в нем был деятельностный подход.

Энциклопедичность «Русской Правды» несомненна. Этот памятник письменности дает возможность носителю современного русского языка увидеть систему ценностей далеких предков, проследить особое отношение к личной собственности, отметить активное деятельностное начало в познании окружающего мира, посмотреть на то, кем мы были и что с нами стало. В этом - неустаре- 
вающая ценность «Русской Правды» для всех последующих поколений.

\section{ПРИМЕЧАНИЕ}

1 Здесь и далее древнерусские примеры даются в упрощенной графике с использованием букв современного алфавита (кроме ъ).

\section{СПИСОК ЛИТЕРАТУРЫ}

Апресян, Ю. Д. Избранные труды : в 2 т. Т. 2 : Интегральное описание языка и системная лексикография / Ю. Д. Апресян. - М. : Языки русской культуры, 1995. - 767 с.

Арутюнова, Н. Д. Русское предложение. Бытийный тип / Н. Д. Арутюнова, Е. Н. Ширяев. - М. : Русский язык, 1983. - 198 с.

Арутюнова, Н. Д. Язык и мир человека / Н. Д. Арутюнова. - М. : Языки русской культуры, 1999. - $896 \mathrm{c}$.

Бирюкович, Р. М. Именование ситуаций существования и обладания в языках различных структурных типов / Р. М. Бирюкович // Номинативные свойства языковых единиц : межвуз. сб. науч. тр. Саратов : Саратов. гос. ун-т, 1990. - С. 3-12.

Вайс, Д. Смысловой потенциал посессивного отношения и его текстуальная обусловленность в современном русском языке / Д. Вайс // Сокровенные смыслы. Слово. Текст. Культура : сб. ст. в честь Н. Д. Арутюновой / отв. ред. Ю. Д. Апресян. - М. : Языки славянской культуры, 2004. C. 283-295.

Гиро-Вебер, М. В защиту глагола ИМЕТЬ / М. Гиро-Вебер, И. Микаэлян // Сокровенные смыслы. Слово. Текст. Культура : сб. ст. в честь Н. Д. Арутюновой / отв. ред. Ю. Д. Апресян. - М. : Языки славянской культуры, 2004. - С. 54-68.

Живов, В. М. История русского права как лингвосемиотическая проблема / В. М. Живов // Разыскания в области истории и предыстории русской культуры. - М. : Языки славянской культуры, 2002. - C. 187-290.

Иванов, Вяч. Вс. Славянский, балтийский и раннебалканский глагол. Индоевропейские истоки / Вяч. Вс. Иванов. - М. : Наука, 1981. - 271 с.

Кацнельсон, С. Д. Историко-грамматические исследования. Т. 1 : Из истории атрибутивных отношений / С. Д. Кацнельсон. - М. ; Л. : АН СССР, 1949. 385 c.

Мещанинов, И. И. Глагол / И. И. Мещанинов. - М. ; Л. : Наука, 1948. - 185 с.

Милованова, М.В.Категория посессивности в русском и немецком языках в лингвокультуроло- гическом освещении / М. В. Милованова. - Волгоград : Волгогр. науч. изд-во, 2007. - 408 с.

Мишланов, В. А. Глагол БЫТТЬ в русском синтаксисе / В. А. Мишланов // Изменяющийся языковой мир : докл. Междунар. науч. конф. (Пермь, Перм. ун-т, 12-17 нояб. 2001 г.). - Пермь : [б. и.], 2002. - С. 45-47.

Селиверстова, О. Н. Труды по семантике / О. Н. Селиверстова. - М. : Языки славянской культуры, 2004. - 960 с.

Цитович, П. П. Исходные моменты в истории русского права наследования / П. П. Цитович. - Харьков : Университетская типография, 1870. - 173 с.

Babby, L. H. Existential sentences and negation in Russian / L. H. Babby. - Ann Arbor : Karoma Publishers, 1980.-180 p.

Bally, C. L'expression des idées de la sphére personelle et de solidarité dans les langues indoeuropéennes / C. Bally // Festschrift Louis Gauchat / F. Frankhauser, J. Jud (eds.). - Arau : Sauerländer, 1926. - P. 68-78.

Baron, I. Semantics of the verb HAVE / I. Baron // Dimensions of possession. Typological Studies in Language / I. Baron, M. Herslund, F. SØrensen (eds.). Copenhagen : John Benjamins, 2001.- Vol. 47. - P. 2-25.

Benveniste, E. 'Etre' et 'avoir' dans leurs fonctions linguistiques / E. Benveniste // Problèmes de linguistique générale. - Paris : Éditions Gallimard, 1966. - T. 1. - P. 187-207.

Clark, E. V. Locationals: Existential, locative and possessive constructions / E. V. Clark // Universals of Human Language. Vol. 4: Syntax / ed. by J. Greenberg. Stanford : Stanford University Press, 1978. - P. 85-126.

Dingley, J. Iměti in the Laurention Redaction of the Primary Chronicle / J. Dingley // The Language and Verse of Russia: In Honor of Dean S. Worth. On his sixty-fifth birthday. - M. : Vostochnaia Literatura Publishers, 1995. - P. 80-87.

Heine, B. Possession. Cognitive sources, forces and grammaticalization / B. Heine. - Cambridge : Cambridge University Press, 1997. - 274 p.

Isačenko, A. V. On 'HAVE' and 'BE' Languages / A. V. Isačenko// Slavic Forum. Essays in Linguistics and Literature / ed. by M. S. Flier. - The Hague ; Paris : Mouton, 1974. - P. 43-77.

Lyons, J. A note on possessive, extensional and locative sentences / J. Lyons // Foundations of Language. - 1967. - Vol. 3. - P. 390-396.

Paillard, D. Enonciation et determination en russe contemporain / D. Paillard. - Paris : Institut d'studes slaves, 1984. $-460 \mathrm{p}$.

Seiler, H. The operationel bases of possession. A dimensional approach revisited / H. Seiler // Dimensions of possession. Typological Studies in Language / I. Baron, M. Herslund, F. SØrensen (eds.). - Copenhagen : John Benjamins, 2001.- Vol. 47. -P. 27-40. 


\section{ИСТОЧНИКИ И СЛОВАРИ}

РП КР - Русская Правда (Краткая редакция) // Собрание текстов. Библиотека литературы Древней Руси. Т. 4. - Электрон. текстовые дан. - Режим доступа: lib.pushkinskijdom.ru. - Загл. с экрана.

РП ПР - Русская Правда (Пространная редакция) // Собрание текстов. Библиотека литературы Древней Руси. Т. 4. - Электрон. текстовые дан. - Режим доступа: lib.pushkinskijdom.ru. - Загл. с экрана.

Преображенский-Преображенский, А. Этимологический словарь русского языка / А. Преображенский. - М. : Тип. Г. Лисснера и Д. Собко, 1910 1914. $-534 \mathrm{c}$.

CPЯ XI-XVII - Словарь русского языка XIXVII вв. - М. : Наука, 1975-2015. - Вып. 1-30.

Срезневский - Срезневский, И. И. Словарь древнерусского языка : в 3 т. / И. И. Срезневский. М. : Книга, 1989.

Фасмер - Фасмер, М. Этимологический словарь русского языка : в 4 т. / М. Фасмер ; пер. с нем. и доп. О. Н. Трубачева. - М. : Астрель, 2004.

Черных - Черных, П. Я. Историко-этимологический словарь : в 2 т. / П. Я. Черных. - М. : Русский язык, 1999.

\section{REFERENCES}

Apresyan Yu.D. Izbrannye trudy: v 2 t. T. 2: Integralnoe opisanie yazyka i sistemnaya leksikografiya [Selected works. In 2 vols. Vol. 2: Integral description of language and systemic lexicography]. Moscow, Yazyki russkoy kultury Publ., 1995. 767 p.

Arutyunova N.D., Shiryaev E.N. Russkoe predlozhenie. Bytiynyy tip [Russian Sentence. The Existential Type]. Moscow, Russkiyyazyk Publ., 1983. 198 p.

Arutyunova N.D. Yazyk i mir cheloveka [Language and the Human World]. Moscow, Yazyki russkoy kultury Publ., 1999. $896 \mathrm{p}$.

Biryukovich R.M. Imenovanie situatsiy sushchestvovaniya i obladaniya v yazykakh razlichnykh strukturnykh tipov [Naming situations of existence and possession of different structural types in the languages]. Nominativnye svoystva yazykovykh edinits: mezhvuz. sb. nauch. tr. [Nominative properties of language units: interuniversity collection of scientific works]. Saratov, Saratov. gos. un-t. Publ., 1990, pp. 3-12.

Vays D. Smyslovoy potentsial posessivnogo otnosheniya i ego tekstualnaya obuslovlennost $\mathrm{v}$ sovremennom russkom yazyke [Semantic potential of possessive relationship and its textual conditioning in modern Russian]. Apresyan Yu.D., ed. Sokrovennye smysly: Slovo. Tekst. Kultura: sb. statey $v$ chest N.D. Arutyunovoy [The Deepest Meanings: Word. Text. Culture: Collected articles in honor of N. D.
Arutyunova]. Moscow, Yazyki slavyanskoy kultury Publ., 2004, pp. 283-295.

Giro-Veber M., Mikaelyan I. V zashchitu glagola IMET [Protection of the verb TO HAVE]. Apresyan Yu.D., ed. Sokrovennye smysly: Slovo. Tekst. Kultura: sb. statey $v$ chest N.D. Arutyunovoy [The Deepest Meanings: Word. Text. Culture: Collected articles in honor of N. D. Arutyunova]. Moscow, Yazyki slavyanskoy kultury Publ., 2004, pp. 54-68.

Zhivov V.M. Istoriya russkogo prava kak lingvosemioticheskaya problema [The history of Russian law as a linguosemiotic problem]. Razyskaniya $v$ oblasti istorii i predystorii russkoy kultury [Research in the field of history and prehistory of Russian culture]. Moscow, Yazyki slavyanskoy kultury Publ., 2002, pp. 187-290.

Ivanov V.V. Slavyanskiy, baltiyskiy $i$ rannebalkanskiy glagol. Indoyevropeyskiye istoki [Slavic, Baltic and early Balkan verb. Indo-European origins]. Moscow, Nauka Publ., 1981. 271 p.

Katsnelson S.D. Istoriko-grammaticheskiye issledovaniya. T. 1: Iz istorii atributivnykh otnosheniy [Historical and grammatical research. Vol 1: From the history of attributive relations]. Moscow, Leningrad, AN SSSR Publ., 1949. 385 p.

Meshchaninov I.I. Glagol [The verb]. Moscow, Leningrad, Nauka Publ., 1948. 185 p.

Milovanova M.V. Kategoriya posessivnosti vrusskom $i$ nemetskom yazykakh v lingvokulturologicheskom osveshchenii [Category of possessiveness in the Russian and German languages in linguocultural coverage]. Volgograd, Volgogradskoe nauchnoe izd-vo, 2007. 408 p.

Mishlanov V.A. Glagol BYT v russkom sintaksise [The verb TO BE in the Russian language syntax]. Izmenyayushchiysya yazykovoy mir: Dokl. Mezhdunar. nauch. konf. (Perm, Perm. un-t, $12-$ 17 noyab. 2001 g.) [Changing World: Proceedings of the conference]. Perm, 2002, pp. 45-47.

Seliverstova O.N. Trudy po semantike [Works on semantics]. Moscow, Yazyki slavyanskoy kultury Publ., 2004. 960 p.

Tsitovich P.P. Iskhodnyye momenty $v$ istorii russkogo prava nasledovaniya [The initial aspects in the history of Russian inheritance law]. Kharkov, Universitetskaya tipografiya Publ., 1870. 173 p.

Babby L.H. Existential sentences and negation in Russian. Ann Arbor, Karoma Publishers, 1980. 180 p.

Bally C. L'expression des idées de la sphére personelle et de solidarité dans les langues indoeuropéennes. Frankhauser F., Jud J., eds. Festschrift Louis Gauchat. Arau, Sauerländer, 1926, pp. 68-78.

Baron I., Herslund M. Semantics of the verb HAVE. Baron I., Herslund M., SØrensen F., eds. Dimensions of possession. Typological Studies in Linguage. Vol. 47. Copenhagen, John Benjamins, 2001, pp. 2-25. 
Benveniste E. 'Etre' et 'avoir' dans leurs fonctions linguistiques. Problemes de linguistique générale. Vol. 1. Paris, Éditions Gallimard, 1966, pp. 187-207.

Clark E.V. Locationals: Existential, locative and possessive constructions. Greenberg J., ed. Universals of Human Language. Vol. 4: Syntax. Stanford, Stanford University Press, 1978, pp. 85-126.

Dingley J. Iměti in the Laurention Redaction of the Primary Chronicle. The Language and Verse of Russia. In Honor of Dean S. Worth. On his sixty-fifth birthday. Moscow, Vostochnaya Literatura Publ., 1995, pp. 80-87.

Heine B. Possession. Cognitive sources, forces and grammaticalization. Cambridge, Cambridge University Press, 1997. 274 p.

Isačenko A.V. On 'HAVE' and 'BE' Languages. Flier M.S., ed. Slavic Forum. Essays in Linguistics and Literature. Hague; Paris, Mouton, 1974, pp. 43-77.

Lyons J. A note on possessive, extensional and locative sentences. Foundations of Language, 1967, vol. 3, pp. 390-396.

Paillard D. Enonciation et determination en russe contemporain. Paris, Institut d'études slaves, $1984.460 \mathrm{p}$.

Seiler H. The operational bases of possession. A dimensional approach revisited. Baron I., Herslund M., SØrensen F., eds. Dimensions of possession. Typological Studies in Linguage. Vol. 47. Copenhagen, John Benjamins, 2001, pp. 27-40.

\section{SOURCES AND DICTIONARIES}

Russkaya Pravda (Kratkaya redaktsiya) [Russkaya Pravda (short version)]. Sobranie tekstov. Biblioteka literatury Drevney Rusi. T. 4 [Collection of texts. Library of the literature of ancient Russia. Vol. 4]. Available at: lib.pushkinskijdom.ru.

Russkaya Pravda (Prostrannaya redaktsiya) [Russkaya Pravda (full version)]. Sobranie tekstov. Biblioteka literatury Drevney Rusi. T. 4 [Collection of texts. Library of the literature of ancient Russia. Vol. 4]. Available at: lib.pushkinskijdom.ru.

Preobrazhenskiy A. Etimologicheskiy slovar russkogo yazyka [Etymological Dictionary of Russian language]. Moscow, Tip. G. Lissnera I D. Sobko Publ., 1910-1914. $534 \mathrm{p}$.

Slovar russkogo yazyka XI-XVII vv. [Dictionary of the Russian Language. The 11-17th Centuries]. Moscow, Nauka Publ., 1975-2015, vol. 1-30.

Sreznevskiy I.I. Slovar drevnerusskogo yazyka: $v 3 t$. [Dictionary of the ancient Russian language. In 3 vols]. Moscow, Kniga Publ., 1989.

Fasmer M. Etimologicheskiy slovar russkogo yazyka: $v 4 t$. [Etymological Dictionary of the Russian language. In 4 vols]. Moscow, Astrel Publ., 2004.

Chernykh P.Ya. Istoriko-etimologicheskiy slovar: $v 2 t$. [Historical and etymological dictionary. In 2 vols]. Moscow, Russkiy yazyk Publ., 1999.

\section{Information About the Author}

Marina V. Milovanova, Doctor of Sciences (Philology), Professor, Department of Russian Language and Documentation Studies, Volgograd State University, Prosp. Universitetsky, 100, 400062 Volgograd, Russian Federation, iryas@volsu.ru, http://orcid.org/0000-0002-6198-6972.

\section{Информация об авторе}

Марина Васильевна Милованова, доктор филологических наук, профессор кафедры русского языка и документалистики, Волгоградский государственный университет, просп. Университетский, 100, 400062 г. Волгоград, Российская Федерация, iryas@volsu.ru, http://orcid.org/00000002-6198-6972. 